\title{
景観条例に基づくデザイン誘導制度の運用実態と課題 一岐阜県古川町の歴史的景観地区を対象として一 \\ DESIGN REVIEW BY ORDINANCE TO CONTROL TOWNSCAPE \\ A case of histric district in Furukawa-cho, Gifu prefecture
}

\author{
佐 野 雄 二*, 岡 崎 篤 行**, 高見沢 邦郎***, 西 村 幸夫**** \\ Yuji SANO, Atsuyuki OKAZAKI, Kunio TAKAMIZAWA \\ and Yukio NISHIMURA
}

\begin{abstract}
The purpose of this study is to realize design review by ordinance to control townscape in Furukawa-cho, Gifu prefecture. And we also aim to acquire the challenge after this. Based on field survey and hearing, we analyze actual condition of the procedure and details of advice by the ordinance and clear up the tendencies of a grant used as method to review. As a result, there are six problems of the management. These causes are closely related with system of the ordinance. It is necessary to improve details of the procedure and to keep fairness of the ordinance.
\end{abstract}

Keywords: Historic District,Ordinance to Control Townscape, Design Review, Furukawa-cho 歴史的景観地区, 景観条例, デザイン誘導, 古川町

\section{1 研究の背景と目的}

景観条例等によるデザイン誘導制度では、景観形成地区を指定し、 建築物の一定の行為について届出を義務づけ、協議・指導等を行い地 域の目標とする景観へ誘導を図ることが一般的である。

このようなデザイン誘導制度が有効に機能を果たすためには、(1)届 出手続きの過程で生ずる課題と、(2)デザイン誘導内容に関係する課題 があろう。具体的には、(1)では協議・指導等の具体的なデザイン誘導 を行う前提として、制度によって義務づけられた届出やその期間が等 しく守られるか、に注目する必要があり、(2)では個々の建築物がデザ イン誘導の目標となる建築物像 (以下、目標建築物像) に近づくため に行われる、協議・指導等の内容や助成制度等の手法が、結果として 建築物によ゙のように影響しているかを考察することが重要であると考 える。

本研究の対象地である岐阜県吉城郡古川町の中心市街地は、文化財 的価値の高い建築物は少ないが、地域の伝統的様式を継承した新しい 建築物により統一感のある町並みが形成されつつある。そのような地 域の特性を活かすため、新築される建築物のデザイン誘導を主な目的 とした「飛騨古川ふるさと景観条例（以下、景観条例）」が平成 8 年 に施行された。

筆者らはこれまでに、同町での住民参加による景観条例の策定に関

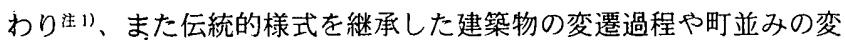

容、近年の新しい外観デザインの生成について、同町の町並み景観形 成の現在に至るまでを明らかにしてきた。そして景観条例の施行によ りデザイン誘導が制度化されたことが、町並み景観の形成に与える影 響についての検証を今後の課題としてきた1)。

そこで本研究は、前記(1)(2)のデザイン誘導制度の課題について調 查・分析を行う。同町の「飛騨古川ふるさと景観条例」における「歴 史的景観地区」を対象として、景観条例施行後に改修注2)された建築 物に着目する。まず 2 章で同町のデザイン誘導制度の概要と特徵を示 し、3章では(1)の課題に対して届出の傾向と届出時期の実態を把握す る。4 章では(2)の課題に対して外観デザインの類型化により、その多 様化の実態と助成制度を活用した建築物の傾向を明らかにする。 5 章 では関倸者によるヒアリングを通じて $3 \cdot 4$ 章で明らかにした運用実 態の問題点の要因を明らかにする。最後に 6 章で課題の整理、改善策 を検討する。なお現地での調查期間は平成 12 年 7 月〜 13 年 3 月にか けて、延べ18日間である。

本稿と類似する研究としてはこれまでに、神戸市を対象とした建築 デザイン誘導制度を建築主・設計者へのアンケートにより制度への対 応状況、評価構造を分析する研究2)や、金沢市において条例に基づく 景観行政施策を対象とした研究 ${ }^{3)}$ 、一般的市街地における大規模建築 物等を対象とした建築デザインの誘導的施策を分析する研究·) があ る。また伝統的建造物群保存地区を対象として景観変容とその要因を
* フリーランス . 修士 (工学)

** 新潟大学工学部建設学科 助教授・博士 (工学)

****東京都立大学大学院工学研究科建築学専攻 教授・工博

**** 東京大学大学院工学系研究科都市工学専攻 教授・工博

\section{Freelance, M. Eng}

Assoc. Prof., Dept. of Civil Eng and Arch., Faculty of Eng., Niigata Univ., Dr. Eng. Prof., Dept. of Arch., Graduate School of Eng., Tokyo Metropolitan Univ., Dr. Eng. Prof., Dept. of Urban Engineering, Graduate School of Eng., Univ. of Tokyo, Dr. Eng. 
明らかにした研究 (5) か)がある。本研究の特徵は、歴史的市街地におけ る住宅等の小規模な建築を対象とした景観条例を対象として、届出手 続きやデザイン誘導の協議・指導の実態をヒアリングを通して明らか にし、デザイン誘導制度の問題点とその要因の考察を試みている所に ある。

\section{2 デザイン荟導の仕組みと目標建築物像}

\section{2-1 届出手続きとデザイン唡遵の流れ}

飛騨古川ふるさと景観条例では、市街地の中心部 $35.8 \mathrm{ha}$ (建物数 約 1350 戸、人口約 4000 人) 注3) を「歷史的景観地区」に指定し、一 定の行為に対して届出（以後、行為届出）を義務づけている注け）。 た、助成基準に基づき建築物等の外観を周囲の伝統的様式を基調とし た景観に調和させる修景に対して、費用の $1 / 3$ 以内 80 万円を上限と して助成を行っている（表 1)。

景観条例に関わる届出手続きは、同町の町づくり振興課が空口と なっており、注5)届出られた行為は同条例において位置づけられた「都 市景観審議会」注6)によって協議基淮に基づき協議が行われる。その 際外観の改修内容についての議論及び改修に対する助成の有無や、助 成を行うための変更条件について意見がまとめられる。その結果をも とに担当課より建築主側に対して助言・指導が行われる。そして工事 完了後に、都市景観審議会から助成額についての最終的な意見が行政 に答申される。(図 1)

また、建築主は行為届出を建築確認申請手続きに入る 4 週間前まで に提出することとされているが、これは届出のあった行為について都 市景観審議会を開催し、協議の後に建築主に対し指導・助言が行わ れ、届出書を受理し、建築確認申請の手続きにはいるために必要な期
間を想定したものであるは7?。尚、同条例は奨励的な条例であるとし て罰則は定めず、指導・助言・勧告にとどまる。

また古川町の場合、建築確認申請の受付は同町の建設課で行われ、 岐阜県飛騨建築事務所注8) の建築主事により確認が行われている。

協議の主体となる都市景観審議会の委員は、住民の代表や建築関連 の各団体の代表等、全員が古川町民の 10 名以内で構成されている" 9)。是非の判断が難しい建築デザイン誘導の協議の場に、被誘導側と もなりうる地域住民が参画し、個々の改修に対して意見を述べる場が 設けられている点は、同町のデザイン誘導制度の大きな特徵である。

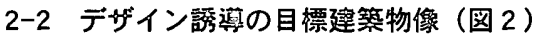

デザイン誘導の目標建築物像は町並みの特徵を踏まえ以下があげら れる。ひとつは地域の伝統的様式を継承した木造真壁造り・切妻平入 りで、各階の庇は出析によって支持され、その肘木には唐草模様の 「雲」と呼ばれる装飾が施された建築物＜新町家＞である。

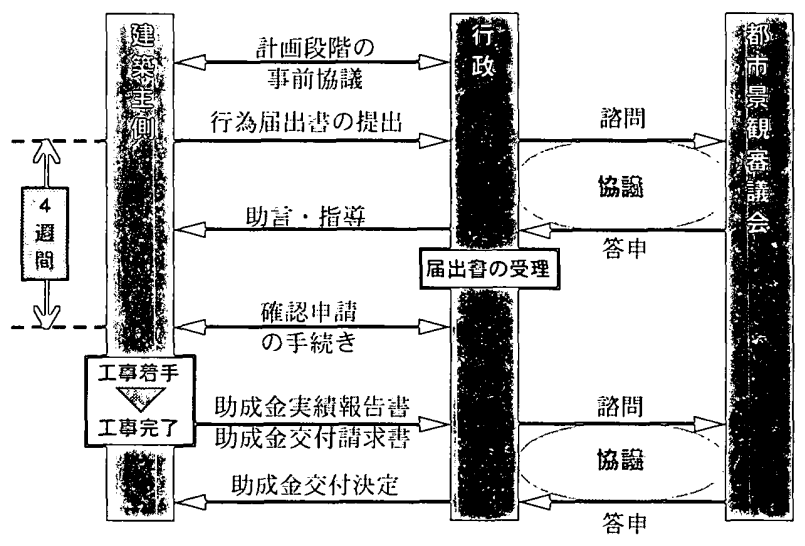

図 1 届出手続きの流れ

表 1 協初基準と助成基準の主な項目

\begin{tabular}{|c|c|c|}
\hline 项目 & 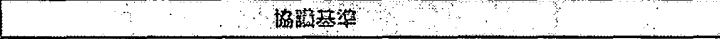 & a \\
\hline 全解 & 周囲の町並みを基調とした篗笅を著しく損なわないものとする。 & 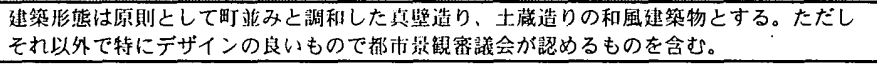 \\
\hline 高を & $\begin{array}{l}1: \text { 階数は原則として3 跸建て以下とする。 } \\
2: 2 \text { 階軒器が近傍の屋台荿の軒高を著しく越えないよう配虑する。 }\end{array}$ & 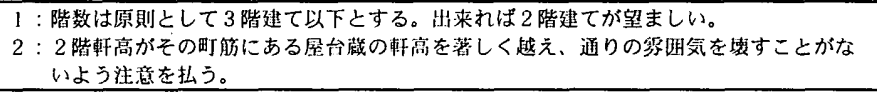 \\
\hline 鋻面缩 & 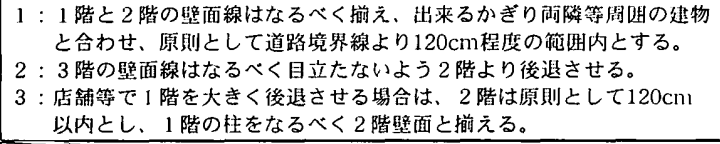 & 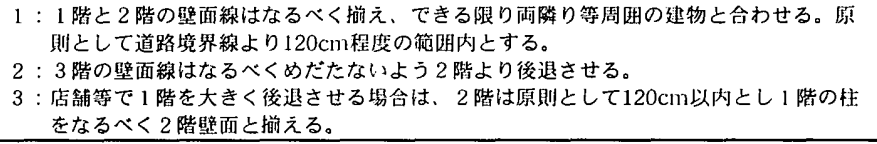 \\
\hline 经造 & & 主要棰造はできるだけ在来棰法による木造とする。 \\
\hline 外琵 & 周囲の乲䘽を著しく損なわないものとする。 & 周围と伝統様式を基調とし景観に調和した真壁造り、土蔵造りの外観とする。 \\
\hline 犀根 & 出来る限り傾斜屋根として、周囲の是観を著しく損なわないものとする。 & 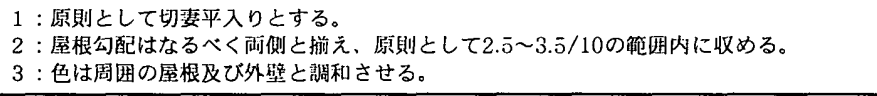 \\
\hline 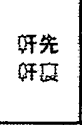 & 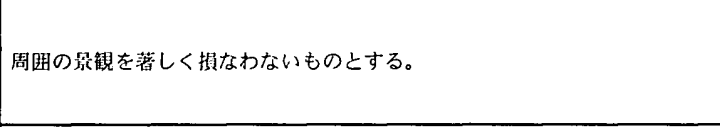 & 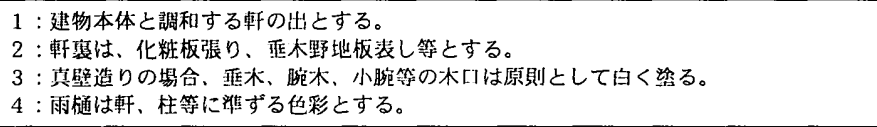 \\
\hline 渭口部 & 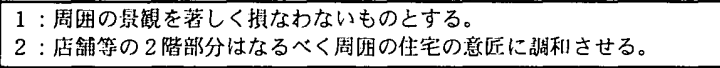 & 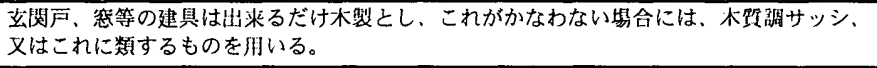 \\
\hline 色影 & 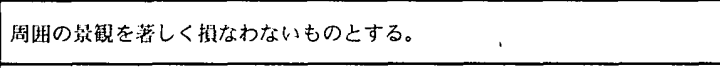 & 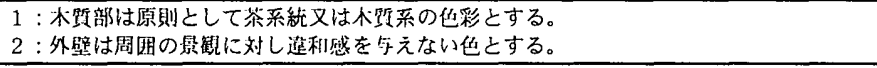 \\
\hline 铅结 & 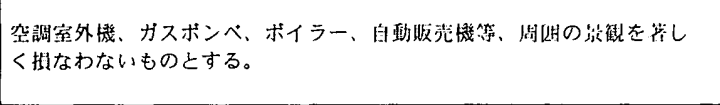 & 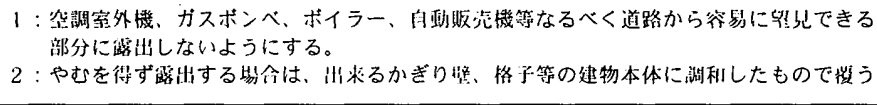 \\
\hline 外植 & 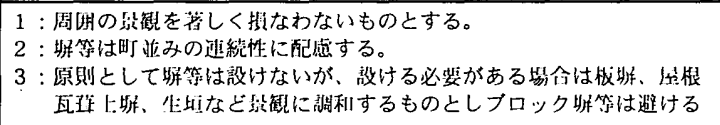 & 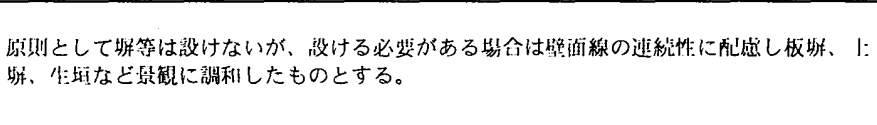 \\
\hline 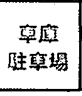 & 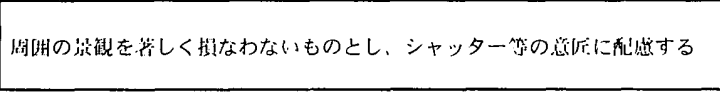 & 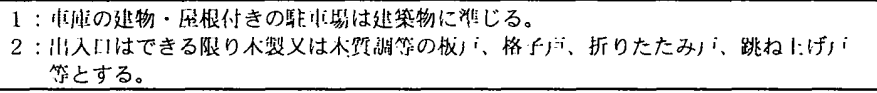 \\
\hline
\end{tabular}


そして、その新町家の原型となった地域の伝統的な建築物く伝統町 家〉と、町並みの特徽のひとつであるく土蔵〉である。注10) またこれ ら以外に目標建築物像とは異なるデザインの建築物であっても都市景 観審議会で認めるものは優良なデザインとして奨励している。

このように同町のデザイン誘導は 3 種類の明確な目標建築物像を中 心とし、それ以外にも優良なデザインを積極的に取入れることを特徵 としている。それらは特に助成基準の項目に反映されている（表 1)。

\section{3 建築物の改修状況と行為届出の提出傾向}

\section{3-1 歴史的景観地区内での建築物の改修の状況（表 2 )}

歴史的景観地区内での建築物の改修状況を把握するため、建築確認 概要書と行為届出から現地にて改修の現状を調査した。双方から把握 された改修は「確認申請のみ」「確認申請及び行為届出」「行為届出の み」の 3 種類に分類することができる。景観条例施行後の 4 年間に、 歴史的景観地区内の改修は全体で142件である。そのうち 2 件は門及 び塀、看板の設置であり、建築物では 140 件となる。工事種別では増 築が最も多く (68 件)、次いで新築（62 件）、ファサード改修注 11 ）(5 件)、改築（3 件）移転（2 件）である。

\section{3-2 望見性からみた改修類型亡行為届出の提出傾向}

同地区において建築確認の必要な行為には、基本的に景観条例にお ける行為届出も必要とされる。表 2 の「確認申請のみ」の建築物 50 件については、行為届出が無く協議・指導を経ていないが、これらが 全て問題というわけではない。行為届出には景観上の望見性注12) が考 慮されるため、その全てが協議・指導を経るべき行為とは限らないか らである。そこで、改修のあった 140 件の建築物について、改修部分 の望見性を指標として $\mathrm{A} \sim \mathrm{D}$ の 4 種類に類型化し、類型ごとの届出 状況について分析を行った。

「A: 主な通りに面した部分の改修」は、車両の通行が可能な幅員を 持つ道（以下、主な通り）に面した部分の改修であり、望見性が最も 高く町並み景観上の重要度も高い。140件中 113 件がこの類型に当た る。しかし 113 件中 28 件は行為届出のない（無届け）改修である。 それら無届けの改修にういて改修部分の主な用途をみると「専用住 宅」が 14 件と最も多く、また「車庫・倉庫」及び「店舗（併用・専 用)」に多い。(表 3 )

「B: 路地等に面した部分の改修」は、幅員は狭いが不特定の人が使 用する公共性のある路地に面した部分の改修である。建築物の側面が 望見対象となることが多く、Aに比べ望見性は低くなる。これに該当 する 5 件は全て届出られていない。

「C: 周囲に空地がある改修」は、通りに面さない敷地の奥での改修 であるが、周辺敷地が駐車場等の空地であったり改修部分が周囲の建 築物よりも大きく、当該建物の望見が可能な場合で、望見性は周辺敷 地の今後の状況に左右される。10 件中 5 件が無届けである。

「D：周囲に建物が建て込んでいる改修」は、改修部分が敷地奥に あり、周囲には建物が建込み、通りからは望見できない改修で望見性 は無い。このような類型の 12 件は全て届出られていない。

同条例では、歴史的景観地区内で届出を必要とする行為が行わ㧈る 場合には、「行為部分が道路、公園等の公共施設から見えない部分に 関する行為については届出対象及び助成対象としない」という内規が ある。つまり内規に従えば、 $\mathrm{D}$ は行為届出の対象外としても $\mathrm{ABC}$ は 届出対象となるものである。しかし、現状では $\mathrm{ABC} 128$ 件中 38 件

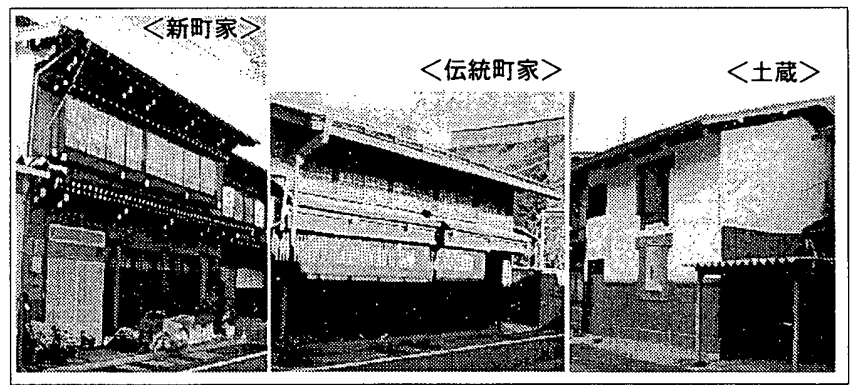

図 2 デザイン誘㝵における目標建築物像の事例

表 2 工事種別からみた改修状況

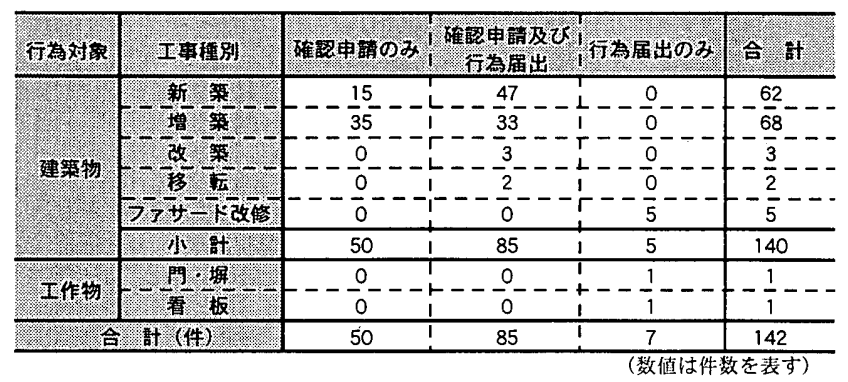
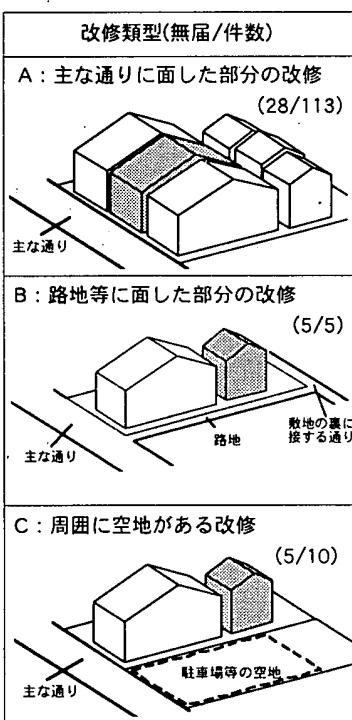

D：周围に建物か建込んでいる改修

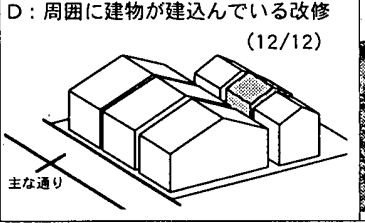

図 3 改修部分の望見性からみた改修類型 表 3 改修類型と改修部分の用途

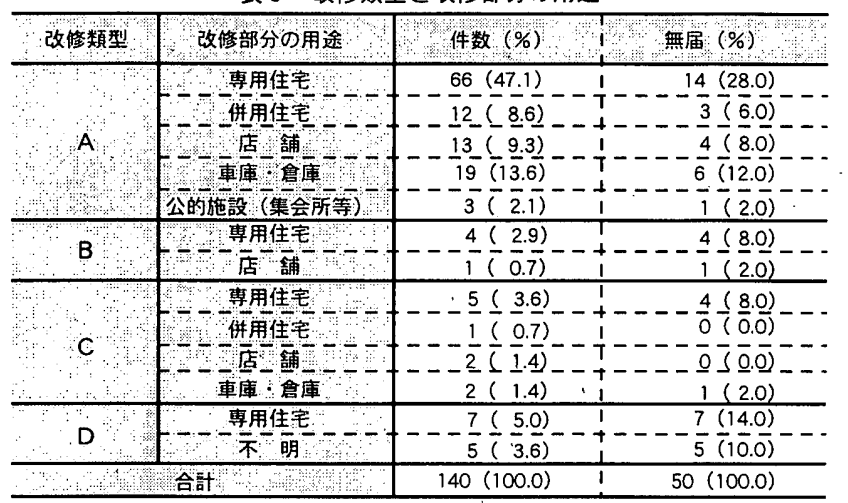


(29.7\%) は届出られていない。望見性の高いAの改修においても 28 件 (24.8\%) が届出を行っておらず、中でも「専用住宅」「店舗（併 用・専用)」「車庫・倉庫」に多い傾向にある。また、Aに比べ「望見 性の低い改修」のB・Cについても届出が少ない。

\section{3-3 行為届出の提出時期}

表 4 は行為届出の提出日から建築確認申請の提出日までの期間を表 している。前述のように、行為届出は確認申請等の手続きに入る 4 週 間前に届出を行い、協議・指導の期間を確保することとされている注 13)。しかし、1 週間以内及び同日に建築確認申請を提出する事例が19 件ずつと最も多い。また行為届出が建築確認申請よりも遅れて提出さ れるケースも 33 件と多くなっている。

行為届出が確認申請の提出に対して大幅に遅れている事例の中に は、景観条例施行以前に確認申請が提出され、施行後に行為届出が出 された景観条例施行当初の例外的事例が 7 件含まれている。それらを 除いても、同日及び建築確認申請が行為届出よりも先に提出されてい る事例では、景観条例において想定されている協議・指導の期間が十 分に確保されていないと考えられる。

\section{4 外観デザインの多様化と助成対象の範囲}

\section{4-1＼cjkstart建築物外観デザインの類型化（図 4）}

改修が行われた個々の建築物がデザイン誘導の目標建築物像（図 2 ) と、どのような関係にあるのかを分析するために、2つの視点か ら分類を行った。ひとつは助成基準の各項目を指標として、個々の改 修を分析する「助成基準項目による分類」である。そしてもうひとつ は改修を全体的に見たときの「デザインの類似性による分類」である 注14)。分析対象は望見性が高く建築物正面の改修の多い、すなわち重 要度の高い「A：主な通りに面した部分の改修」の113 件である。

（1）助成基準項目による分類（図 4の下、表部分参照）

助成基準の各項目のうち外観デザインの傾向を捉えやすい「高さ」 「色彩」「設備機器」「外構」「開口部」「構造」「壁面線」「屋根」「軒先・ 軒裏」「外壁」「車庫・駐車場」の 11 項目を用い、個々の改修を各項 目の内容と比較し、それへの適合・不適合から 4 段階に分類した。項 目のうち「高さ」「色彩」「設備機器」「外構」「開口部」「構造」「壁面 線」「車庫・駐車場」では改修の差異は大きくあらわれないが、「屋根」 「軒先・軒裏」「外壁」との関係で改修の類型が可能である。そのため 各類型は以下のような特徵になる。

〈I : 助成基準を全て満たす改修（27 件）>「高さ」を始め 11 の助 成基準項目を全て満たす改修。

くII : 助成基準を概ね満たす改修 (35 件)>「開口部」や「壁面線」 等一部の項目を満たさないが、目標建築物像の特徵が顕著に表れ る「外壁」「軒先・軒裹」「屋根」は全て満たす改修。

<III：助成基準の一部を満たさない改修（18 件）>目標建築物像の 特徵が顕著に表れる「外壁」「軒先・軒裏」「屋根」の項目のうち 「外壁」を満たさず「屋根」「軒先・軒裏」の両方又はいず狆かを 満た寸改修生 15)。

$\langle\mathrm{V}$ : 助成基準を満たさない改修（33 件）>「外壁」「屋根」「軒先・ 軒裹」の項目のいずれも満たさない改修。

（2）デザインの類似性による分類（図 4の上、写真部分参照）

$<a:$ 伝統町家 $(6$ 件 $)>$ 建設年代も古く地域の伝統的な様式の建築 物ではあるが、これまでに外観に手が加えられていたり又は老朽
表 4 行為届出受付から確認申請提出までの期間

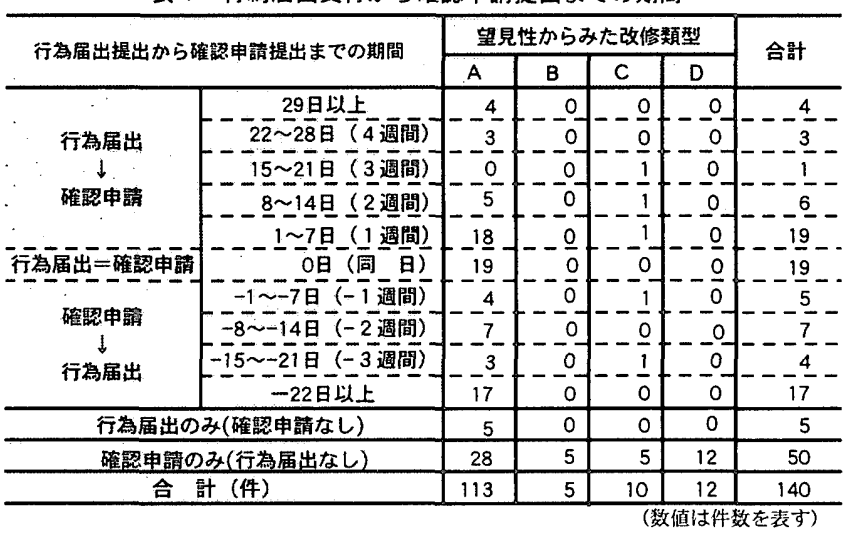

化していたものを用途変更などの契機に復原的に改修したもの。 $<\mathrm{b}$ : 新町家 (54 件) >切妻平入りの伝統的様式を基調とした真壁 造りで出析の庇を持つ目標建築物像の新町家の外観をした建築。 $<c$ : 土蔵風の外観 (4件)>ほぼ完全に土蔵を模したものや白い壁 面を基調とし小さな開口部を設けるなど全体的に土蔵をイメージ した外観の建築物。

$<\mathrm{d}$ : 新町家風の外観（14 件）>伝統的な真壁造りではなく、全体 的な印象は異なるが、軒先・軒裹の意匠や擬似的な柱を取付け真 壁造りを模したもの等、部分的に新町家の特徵を取入れた外観。 $<\mathrm{e}:$ 和風の外観 (2 件) > 3 種類の目標建築物像とは異なるが、切

妻屋根を強調するなど和風の外観とした建築物注 16 。

$<\mathrm{f}$ : 目標建築物像の特徵のない外観 (33 件) $>$ 目標建築物像を意識 せずに建てられた外観の建築物。

「デザインの類似性による分類」では、目標建築物像と同等のく伝

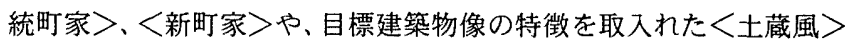
<新町家風 $><$ 和風 $>$ 建築物、《目標建築物像の特徽のない外観 $>$ の建築物の 6 種類に分けられる。なかでも新町家は、全体の約半数 （54 件、47.8\%）を占めている。その反面、約 3 割はく目標建築物像 の特徵のない外観〉である。

そして「助成基準項目による分類」と「デザインの類似性による分 類」を重ね合わせると 10 種類となり多様である。

4-2 助成対象となった建築物の外観傾向（表 5)

同町では助成制度をデザイン誘導の手法として用いている。これま でに望見性の高い「A：主な通りに面した部分の改修」では、113件 中 54 件が助成対象となっている。助成対象となった建築物の改修を 「助成基準の項目による分類」からみると、「I : 助成基淮を全て満た す改修」の 21 件 (77.8\%) や「II：助成基準を概ね満たす改修」の 26 件 (74.3\%) が助成対象となっており、「外壁」「屋根」「軒先・軒 裏」の項目を満たしている目標建築物像と同等の改修であれば、ほぼ 助成対象となっている望 17)。また、「外壁」「屋根」「軒先・軒裏」の項 目を満たさない「IV :助成基準を満たさない改修」は、助成対象となっ ていない。

しかし、「III：助成基準の一部を満たさない改修」において、特に III -dにあたる「新町家風の外観」では、助成を受けた改修が約 $1 / 3$ である。これら目標建築物像と同等とは言えないが、目標建築物像の 特徵を取入れ、町並みに対して配虑がみられる建築物に対しての助成 の有無が、助成基準という外観上の指標のみでは判断できないことを 示しており、客観的な公平性が見出しにくくなっている。 


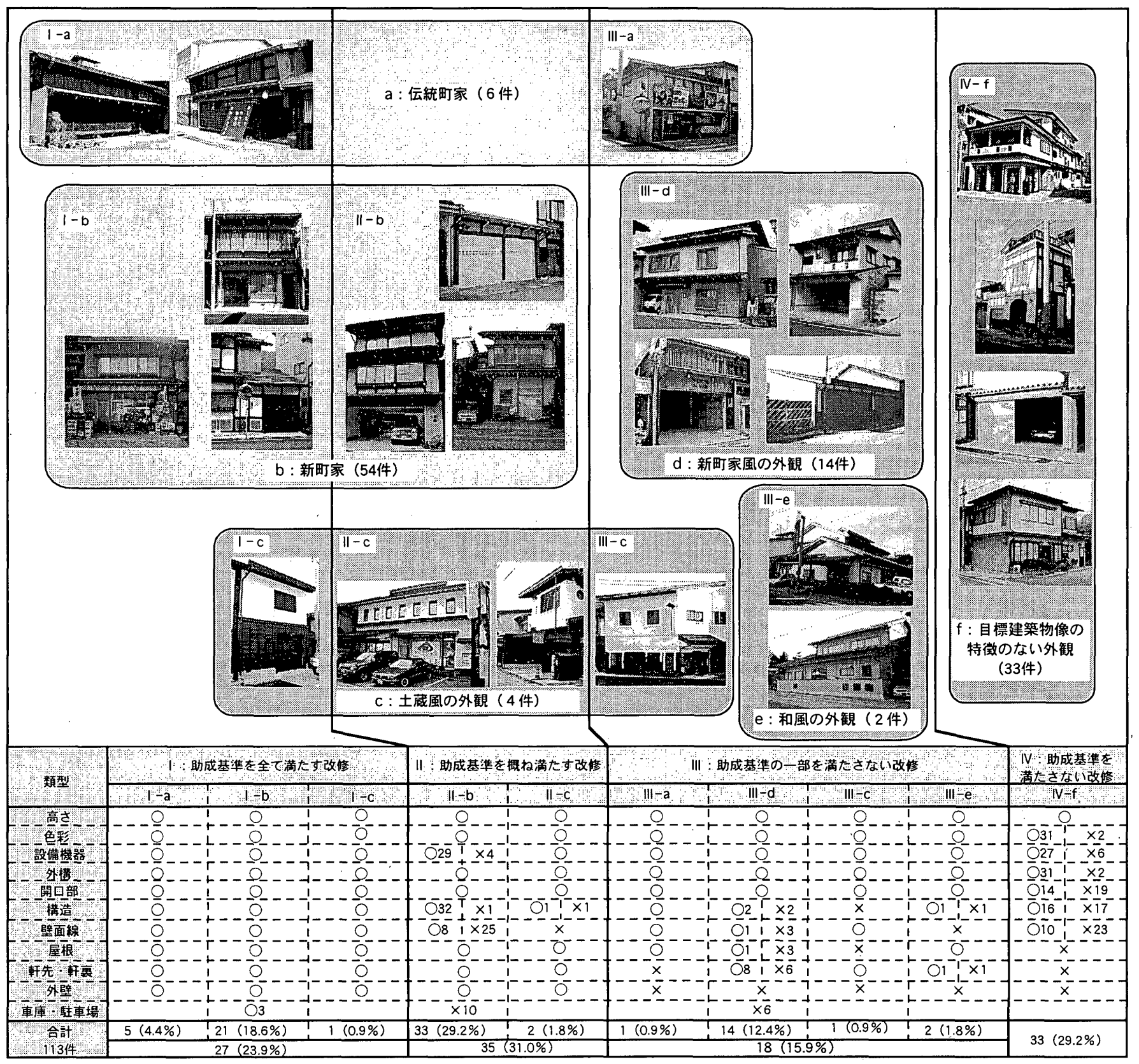

図 4 景観の評価と外観デザインの類型

5 生じている問題点の要因と関係性

$3 \cdot 4$ 章の分析により、以下の 3 点が問題点として考えられる。(1) 景観条例によって義務づけら㧈ている行為届出に対して、届出のない

表 5 助成対象となった建築物の件数別の傾向

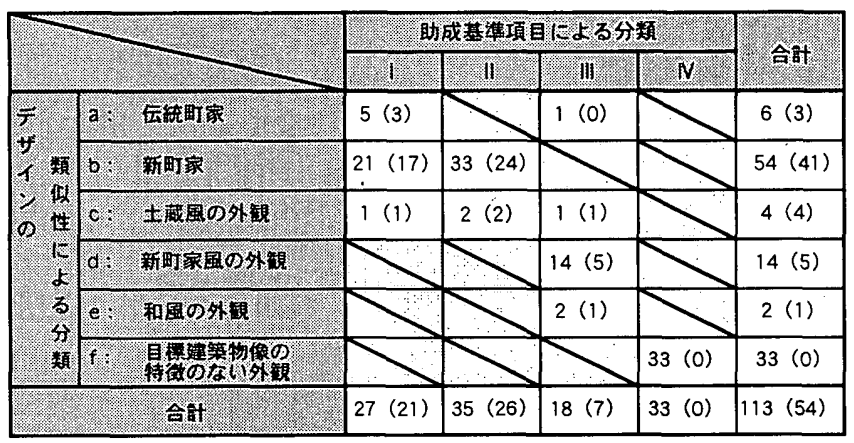

数值は件数を表す。また（）内は助成对象件数
改修があり、それらにはある傾向がみられること。(5-1で分析) (2) 景観条例が想定している協議・指導の期間が十分に確保されていない こと。(5-2 で分析) (3)目標建築物像の特徵を取入れた建築物に対し て、助成の有無が外観による客観的な視点からは明確に判断できず、 公平性が見出しにくいこと。(5-3で分析)

ここでは、それら(1)(2)(3)の問題点の要因を明らかにするために、a) 届出手続きとデザイン誘導・助成制度を関連づけた分析を行うととも に、b）建築主 19 人、設計者 5 人、施工者 3 人より合計 46 件の改修 に至る経緯をヒアリングによって把握、またc）都市景観審議会委員 5 人、行政担当者 3 人から協議・指導の内容をヒアリングした。以上 a）b）c）の作業から問題点が生じている要因を考察する。 


\section{5-1 届出の行われない要因（図 5)}

行為届出を提出せずに改修を行う傾向のある「専用住宅」「店舗（専 用・併用)」「車庫・倉庫」「望見性の低い改修」について、届出の行 われない要因壮18) を整理した。

「専用住宅」「店舗（専用・併用）てでは、目標建築物像とは異なる 外観としたい、又は店舗のイメージと目標建築物像がつくる和風のイ メージが合わない等、歴史的景観地区内であっても景観条例に左右さ れず自由に造りたい、という建築主のデザインに対する指向が目標建 築物像と異なるデザインとしてあらわれるく意識面の問題>がある。 「車庫・倉庫」は、低予算での建築を求められる場合が多い。また屋 根の雪下ろし等の作業の軽減を含めた維持・管理の容易さを求めら れ、鉄骨造を選択する。双方の要求に対応すると、目標建築物像には なりにくいくコスト・技術面の問題〉がある。さらに、「望見性の低 い改修」では、景観上重要ではないと建築主、設計者が判断して目標 建築物像に沿った改修を行う必要性を感じていないく制度認識の問題 $>$ ブある。

これらの要因は全て目標建築物像と異なる改修へとつながってい

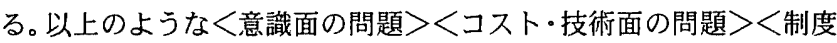
認識の問題 >が、デザイン誘導の行われる協議・指導を回避する要因 とされよう。

また歷史的景観地区内で建築物の行為届出を行う場合には「景観形 成地区内行為届出書」壮19）を必要とし、また助成金を申請する場合に は「景観形成地区建築物等助成金交付申請書」等を提出する ${ }^{200)}$ 。多 くの場合、設計者（建築士）がこれらの手続き書類の作成を担当し、 建築主がその費用を負担する生211。助成対象にならないことが明らか な「目標建築物像の特徵のない外観」の建築物、特に低予算で行われ る改修にとっては大きい負担となり、無届けにつながるもうひとつの 要因となっている注22)。

\section{5-2 協熘・指導期間とデザイン䛪導の対応}

景観条例で想定されている協議・指導期間の不足の要因について は、以下を確認することができる。

行為届出に必要な書類には、着色立面図 (外部仕上明記) 等が含ま れており、行為届出提出時には建築確認申請時とほぼ同様の設計段階 であることが必要となる。建築主による工事期間の指定により建築確 認申請の提出が優先となり、それ以前に求められる行為届出に対する 十分な期間が確保できない。

また、歴史的景観地区内の建築物は同町内の設計者及び施工者によ
ることが多いため浊23)、景観条例の意図に沿ったデザインについては 広く認識されている。目標建築物像に近い改修であれば、協議内容の 予測もつき、指導、助言がなく順調に工事に入れることが予想される ため、求められる期間を確保しなくても支障がない、という判断が設 計者・施工者側にある。これらが要因となり、景観条例で想定してい る協議・指導期間が十分に確保されていない。

このような現状に対して行政と都市景観審議会では、事前協議や行 為届出の提出、或いは直接工事を発見すること等によって、建築物の 改修が明らかになった時点から、工事着手あるいは外観工事の着手に 至る期間までを、実際の協議・指導期間として活用している（図 6 )。 その際、都市景観審議会を開催するか或いは都市景観審議会を開催す る十分な期間が確保できない件については、担当課職員と都市景観審 議会委員の数人が建築主側と直接話し合いを設ける等で協議・指導の 機会を設けて対応している。

既に建築確認が申請されている建築物であっても、変更届けの必要 のない範囲での外観の改善を求めており、協議・指導は可能である。

このように景観条例において想定された協議・指導期間と実際の協 議・指導期間では異なるが、行政・都市景観審議会の柔軟な対応によ り事前に改修が明らかになった件については協議が行われている。

表 6 からもわかるように、行為届出が提出され協議・指導の機会の あった改修の多くは町並み景観への配慮がみられる。「IV : 助成基準 を満たさない改修小いわゆる町並みに調和しない建築物は、行為届 出の提出されない改修に最も多い。

\section{5-3 デザイン誇導内容と助成対象の決定過程}

都市景観審議会で個々の改修について協議が行われる際、その内容 は協議基準を踏まえたものとなるが、議論はより具体的になり、目標 建築物像の外観構成について、より詳細に明文化されている助成基準

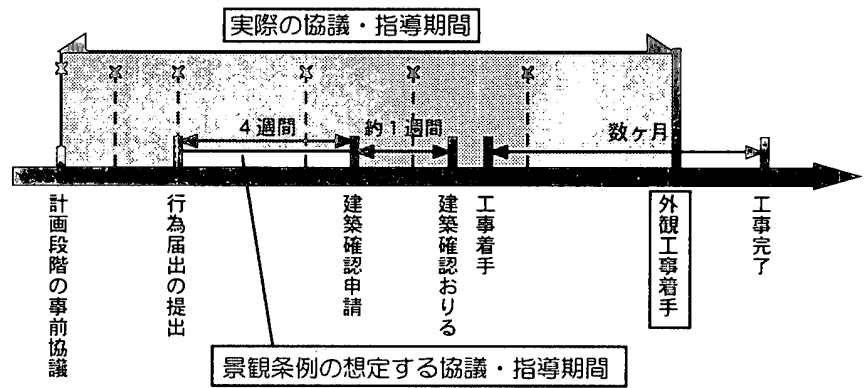

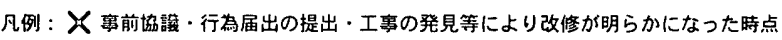

园 6 景観条例の想定する協䜅・指導期間と実際の協淁・指導期間

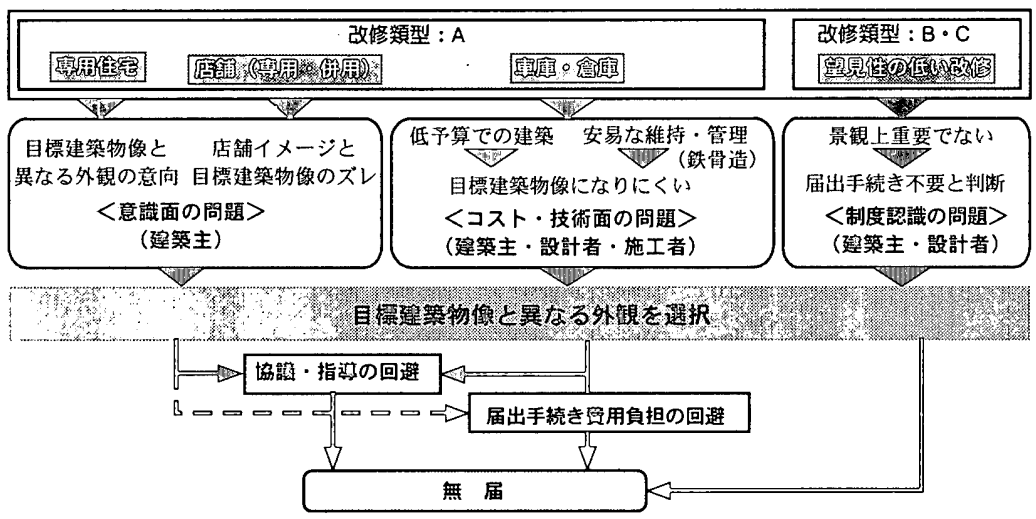

図 5 届出の行われない要因
表 6 行為届出の有無と助成基準項目による分頑

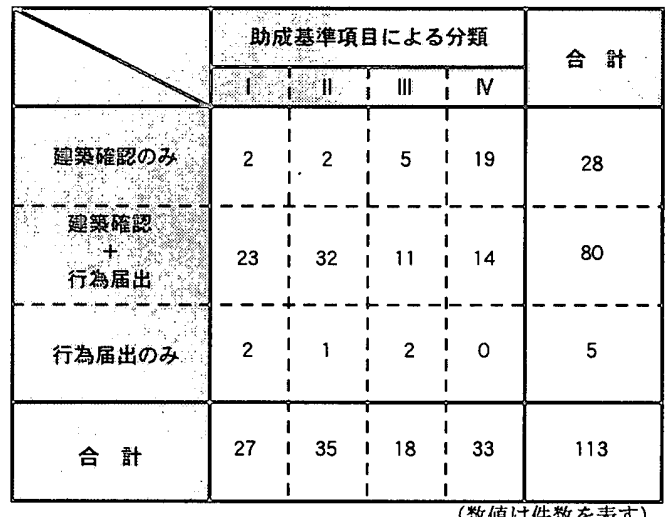


や、助成対象基準(例注24) にかなうように変更点の話合いが行われる。 委員には設計者（建築士）や施工者もいるため、改善にあたつて材質 や施工方法の提案に及ぶことがある。

例えば助成基準による分類で協議前から目標建築物像に近い「I： 助成基準を全て満たす改修」であれば、変更を求める要望は出されな いが、目標建築物像の特徵を持たない大壁造りの外観をした「IV : 助 成基準を満たさない改修」に対しては、特に新町家の特徵である「外 壁」「軒先・軒裹」に対して、擬似的な柱を付け真壁造りに見えるよ うにすることや、軒先・軒裹の意匠について変更の要望が出される。 計画段階ではあるが、建築物の大幅な変更を求めることは実現性が無 いという認識もあり、町並み景観に出来る限り調和するよう部分的な 改善を求めている。その結果、変更の要望が反映されたものは目標建 築物像と同等とはいかないが、「 $\mathrm{c}$ ：土蔵風の外観」「d：新町家風の 外観」「e : 和風の外観」など、目標建築物像の特徴を取入れた外観と なるものが多い主25)。このようにデザイン誘導によって、目標建築物 像へ少しでも近づけるようとすることで、目標建築物像と同等ではな いが、目標建築物像の特徵を持った多様な外観の建築物が生成される 要因のひとつとなる。

そして、助成の有無についての決定は、工事完了後の建築物から判 断されるが、助成基準項目との適合・不適合の判断のみではなく、協 議・指導段階での改善要望が工事完了後の外観にどれだけ反映させよ うとしたか、建築主側の努力も考慮される傾向にある。このように、 デザイン誘導内容と助成制度が密接に関係しているため、助成基準項 目のみから助成対象の判断が出来ない。

\section{6 結論}

以下に本研究において明らかになったことの要点をまとめ、飛騨古 川ふるさと景観条例に基づくデザイン誘導制度について、届出手続き とデザイン誘導内容の課題について述べることとする。

\section{6-1 調査・分析結果の整理}

1 ) 歷史的景観地区内における改修を「望見性からみた改修類型」に よって類型化すると、望見可能な改修のうち約 3 割は行為届出が 提出されていない。そのうち「専用住宅」「店舗（専用・併用）」 「車庫・倉庫」「望見性の低い改修」で無届けの傾向が強い。

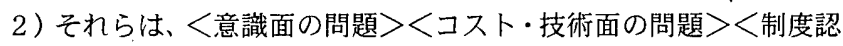
識の問題〉により、デザイン誘導の目標建築物像と異なる外観の 改修となるため、協議・指導の回避を目的として無届けとなる。 また届出手続きの費用の負担も無届けにつながる要因のひとつと なっている。

3 ）景観条例で想定されている協議・指導期間は、届出手続きに必要 な書類の内容による問題と、設計者・施工者側の判断により、十 分に確保されていない。しかし行政や都市景観審議会の柔軟な対 応により、改修が明らかになった時点から工事着手又は外観工事 着手までを協議・指導期間として活用することで、協議・指導の 機会が設けられている。

4) 協議・指導の機会のあった改修の多くは町並み景観への配慮がみ られる。町並みに調和しない「IV : 助成基準を满たさない改修」 は、行為届出の提出されない改修に最も多い。

5 ) デザイン誘導によって目標建築物像へ少しでも近づけるようとす ることにより、目標建築物像の特徵を持った多様な外観の建築物
が生成される。これらはデザイン誘導の効果といえる。

6 ) 目標建築物像の特徵を取入れた建築物に対して助成の有無が、外 観による客観的な視点からは明確に判断できず、公平性が見出し にくい。これは、助成の有無の決定が、助成基準項目との適合・ 不適合の判断のみではなく、協議・指導段階での改善要望が工事 完了後の外観にどれだけ反映させようとしたか、建築主側の努力 も考慮される傾向にあるためである。

\section{6-2 デザイン誘導制度の課題と解決の方向性}

(1)届出手続きの課題について

景観条例に基づくデザイン誘導制度を効果的に運用していくために も、その入口部分に当たる行為届出の徹底が必要であろう。同町では 建築確認の申請時に、景観条例における届出手続きの有無について、 チェックが十分ではなかったことが、行為届出を徹底出来なかった要 因のひとつと考えら㣗る。注26) 解決策としては、確認申請時に景観条 例の届出手続きが行われているかのチェックを行うことと、またそれ らを円滑に行うために担当官同士の情報交換が必要となろう。注27)

行為届出を徽底する手段としては、罰則規定の適用も考えられる。 しかし、一般的に景観条例では法的な根拠の瞹昧さもあり、厳しい罰 則規定を設けている例は少なく、氏名の公表等で対応している事例が ある注28)。同町においても、行為届出の申請者である建築主の氏名の 公表等が考えられるが、地域住民は氏名の公表をせずとも建築主が 解っており、罰則の効果は明確でない。注29)

そして行為届出の際に問題となるのは、届出対象行為の範囲につい てで、景観条例と住民の判断に多少の相違があると思われる点があ る。すなわち古川町の特徴でもある路地景観や、寺院等の半公的な私 有地を取り囲む景観の重要性を考慮すれば、望見性の高い「A：主な 通りに面した部分の改修」だけでなく「B：路地等に面した部分の改 修」及び「C：周囲に空地がある改修」についても届出や協議が考慮 されてよい類型であると考えられる。これら「届出の範囲」について は、どこまでを町並み景観整備の目標とし、何を重要視するかについ て、住民、行政の共通認識が必要であろう。

また、届出手続きの書類については、建築確認申請以前に提出が可 能となるように、改修内容の基本方針やコンセプト時点で提出が可能 な内容に改善することが考えられる。手続き費用の負担についても、 手続き書類を減らす、書類作成の費用に対して助成を行うなどによっ て軽減を図ることが必要であろう。

(2)デザイン誘導内容の課題について

同町のデザイン誘導には、誘導の目標となる目標建築物像が、く伝 統町家 $><$ 新町家 $><$ 土蔵 $>と し て$ 明確に示されており、助成基準や 助成対象基準例で具体的な項目が定められている。そのため目標建築 物像の特徵を持たない建築物に対して、部分的であっても変更の要望 が具体的に指摘できている。結果としては目標建築物像と同等の外観 にはならないが、目標建築物像の特徵を有した外観となる。これら全 てが、町並みに調和した建築物であるとは必ずしも言えないため、ど の程度までの建築物が奖励されるべきであるかは議論が必要である。 ただし、計画・設計が進行した段階で行われるデザイン誘導にとつ て、このような建築物は実質的な効果であると言えよう。

助成対象の判断については、最終的な改修状況からのみ判断する か、指導・助言により改善が得られたことも含めて判断するか、2 段 階あろう。奨励的意義を考慮すれ狆後者の判断基準も妥当性がある。 
しかし、客観的な公平性は暧昧になるおそれがある。古川ではデザイ ン誘導の協議機関として都市景観審議会があり、構成員が被誘導側に もなりうる地域住民であるという点で、助成対象の判断に対しての透 明性と合意が内包されていることに、大きな意義がある。しかし時系 列的に捉えた場合、審議委員の任期による人材の変動、審議を重ねる ことによる議論の熟練により、時系列における判断の公平性には疑問 が生ずる。判断基準が変化することは、変化を許容する景観条例の主 旨においても否定されるべきものではないが、都市景観審議会の自覚 に基づくものでなければならない。その対策としては、助成対象と なつた建築物について定期的に、その基準を検証する機会を設けるこ と等があろう。

以上、古川町の景観条例に基づくデザイン誘導制度について、その 実状の把握から問題点を整理し、届出手続き及び、デザイン誘導内容 の課題とその解決の方向性について述べてきた。本研究の成果を踏ま えて、デザイン誘導制度の運用や制度内容の具多的な改善策について は、行政や都市景観審議会を中心に、地域住民を含めて、今後さらに 議論を深めていくことが課題である。

また本研究の成果は、文化財的価値の高い建築物は少ないが、地域 の伝統的様式を継承した新しい建築物により統一感のある町並みを形 成しようとする地域において、デザイン誘導制度を検討する際にも役 立つ知見を含んでいるものと考えている。

\section{<謝辞〉}

本研究は「飛騨古川町並み研究会」として公益信託大成自然・歴史 睘境基金による助成を得て行った活動の一部である。本稿をまとめる にあたり、研究会メンバーの駒氏、田之下氏、直井氏、竹林氏、加藤 氏、及び古川町町づくり振興課の野村氏、忍氏、建設課の沖村氏、ま た調查に御協力頂いた同町の方々に記して深く謝意を表する。 <補注〉

注 1）景観条例制定までの経緯は、参考文献 7) に詳しく記述されている。 注 2) 本稿では、新筑、增筑、改筑、移転、ファサード改修をまとめて改修と 呼分。

注 3）建物数は地図上より計测し、人口は平成 7 年国勞調查を基に集計した。 注4）歴史的景観地区における建筑物の届出対象行為は「延べ床面積 $10 \mathrm{~m}^{2}$ を越 える新築、增築、改築、移転、大規模の修絙、特殊建築物の用途変更、外観の 模様替え、色彩の変更」である。これは建筑確認（建築物）の必要な行為を包 括し、更に景観整備上重要な「外観の模様替え」「色彩の変更」を含めた構成之 なっている。また、届出の対象は他に「景観重要建築物（全町）「大規模建築 物 (都市計画区域)」「屋外広告物（歴史的景観地区）」「景観樹木（歴史的景観 地区)」「屋外広告物（歴史的景観地区）」等がある。助成対象行為には、「景観 重要建築物 (全町)」「景観樹木 歴史的景観地区)」「屋外広告物（歴史的景観 地区)」「まちづくり景観組織（全町）」等がある。

注 5）平成 9 年度までは、磪認申請と共に景観条例の手続き公口も同町の建設 課が行っていたが、平成 10 年度以降は、役場内の組織の変更により詈観条例 は、まちづくり振興課が担当となり、空口が別れた。

注 6）都市景観審議会は届出の数に応じ、数件の提出があり次第不定期に召集 され開熣される。

注7）法令上の手続きを要しない行為にあっては、当跤行為に着手する日の 4 週間前の期間に相当する。

注 8）所在地は古川町から難れた岐皁県高山市内にある。

注 9）都市景锶審議会の委員の任期は 1 年で、再任も認如られている。

注 10)「答」については、参考文献 1) で詳しく説明を加えている。またく新 町家 $><$ 伝統町家 $><$ 上藏 $>$ は、同じく参将文献 1）において定峷したもので ある。

注 11)「ファサード改修」は建築物外観の軽微な改修、模様䇠え、色彩の変更 であり概ね建築確認の必哭はないのも。

注12）「町並みをみる」人が自由に通行できる道路、公四等の公共施設 (空間) から改修部分の見え方をここでは望見性と称することにする。

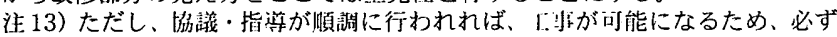

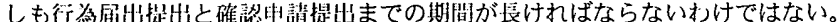
注 14）参考文献 1）において、筆者らは古川町内の建筑物を歷史的な経緯も含

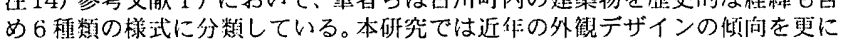

詳細に分析するために、参考文献 1)では「その他」としてまとめていたもの

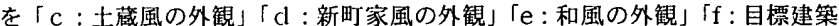
物像の特徵のない外観」に細分類している。

注 15)「外壁」の要件である伝統様式を基調とした真壁造り、土藏造りは目㯲 建築物像の大きな特徵であり、この要件を満たさない改修は目慓建築物像と大 きく巽なる外観となるため、この類型の選別項目とした。

注 16) 古川住民はこの分類にあたる建築物を「数寄屋風」と呼んでいる。これ は建築主側のデザイン意図が目標建築物像とは異なる建筑物であるが、町並み 景観上は和風建築物ということでの配慮がみられる建築物として「和風の外観」 として扱う。

注 17) 助成を受けることについては、建築主の判断であるため目標建築物像に 近い改修であっても申請せずに助成の行われていない改修もある。

注18）届出の行われない主な要因としては、景観条例の存在を知らないことも 考えられる。しかし同町の「飛騨古川ふるさと景観条例」は、策定段階から住 民参加によって進められてきている (参考文献 7 参照)こともあり、同条例に 認知度は高い。本調査における建築主へのヒアリングにおいても、同条例を認 識していない人は19人中1人であった。そして歴史的景観地区内の建築物は同 町内の設計者及び施工者によることが多く、同条例の存在を知らずに建筑する ことはほとんど無く、条例の存在を知らないことが主な要因とはなっていない。 注 19）添付書類として、位置図、着色立面図（外部仕上明記）がある。

注 20) 添付書類として、位置図、配置図兼外構平面図、立面図 (外部仕上明記)、

数量計算書、必要に応じて詳細図、現況カラー写真、助成金算定書、積算根拋 書、申請费見積書等を要し、工事完了後に助成金実績報告書、助成金交付請求 書を提出する。

注 21）設計のみを行う場合は、行為届出にかかる費用は10～15万円。確認申 請の手結きも僧せて行う場合は、一部の書類が重複するために簡略化出来るの で10万円くらい。設計・施工の場合は行為届出及び確認申請等の書類作成費用 は工事费に含めてしまう。感覚としてはサービスとなる。

注 22) 同条例の内規には、建筑物の建策及び全面改修等において各申請に必要 な費用について助成対象となる（かかる費用の $1 / 3$ 上限 50 千円）之記してい るが、予算の関係上現在はこの件については運用されていない。

注 23）ほほ 8 割以上が古川町内の設計者による。次いで高山市、名古屋、(東 京、大阪は 1 件ずつ)

注24）助成対象基準例とは、改修が助成対象となるか、行為を項目ごとに例示 して明確に言及したもの。例えば、「外壁」では京叙壁、ブラスター、下見板镸 等。「軒先・庇」では、雁析造り、化粧垂木表し、箱庇、霧除け等を例示してい る。

注25）ヒアリングで明らかになったものだけでも、「c：土蔵風の外観」「d ： 新町家風の外観」「e : 和風の外锶」のうち、要望が聞き入れられ、改善が図ら れた改修は 5 件確認された。

注 26）具体的には、確認申請の受付のみを行う課と、景覞条例における届出手 続きを扱う担当課・担当官とも異なり、双方の十分な情報交換やチェックがな されていなかったことが要因のひとつであると考えられる。尚、平成 13 年度よ

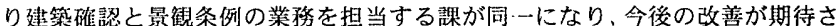
れる。

注 27) 原則としては、景観条例によるデザイン誘導の協議が終了した後に、建 築確認の手続きに入るとされている。建築確認時に景锶条例の届山手続きにつ いてチェックするのでは順番が逆になるが、この建築確鮥の申請時点以前での チェックは奞しい。行為届出の徹底という点について考えれば、この時点での チェックであっても効果があると考える。

注 28）羅則としての氏名の公表には、行政側の違反行為に対する意思表示と、 氏名が公表されることにより、地域に周知されることで、それ以降の活動が行 いにくくなる、と善う意味が含まれる。

注29）例えば現行法制度の枠組みの中では、地区垶西を定めて行為届出の内容

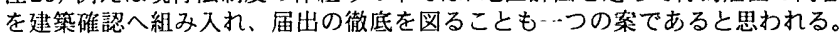
また、归状の変更が許可制となる伝統的建造物群保存地区制度の導入もある。 <参考文献〉

1）佐野雄二,岡崎篤行,高見沢邦郎：伝統的様式を継承した新たな町並み畒観 の形成過程と計画的課題一岐皁県古川町の歴史的市街地を対象として一, 日本 建筑学会計画系詥文集，第531 号, pp.179-185,2000.5

2) 安田丑作,鴄田勝次,三輪康一：建築デザイン誘導による都市景観形成手法 とその評洒に関する研究一神戸市における建築デザイン誘薪事例を通じて一,昭 和 61 年度第 21 回日本都市計画学会学術研究論文焦, No.78,pp.463-468,1986 3）中村和宏，川上光彦: 金沢市における条例に基づく景微衍政施策に関する調 查研究, 1994 年度第 29 回日本都市計画学会学盛研究論文集, No.24,pp.139144,1994

4）李政妸，西村幸夫：师成市街地を対象とした自治体の条例策定による景観コ ントロール施策の展開 一東京都豊島区と新寉区を事例としてー,日本建築学会 計画系論文集，第 504 号,pp.147-153,1998.2

5）金弘已，宗本順三：伝建地区の現状変更行為における位民の建勧希望内容と 町並み変容の研究一近江八幡市を事例として一, 日本建築学会計面系諭文集, 第 518 号, pp.229-236,1999

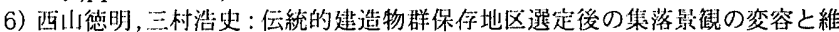
持に関する研究一白川郷荻町合掌集落を事例として一, 日本建筑学会計画系論文 集,第 474 号,pp.151-160,1995

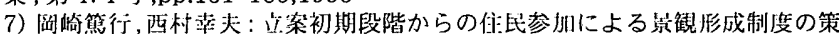

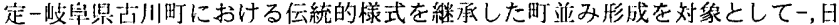
本建築学会計酹系論集,第 537 号,pp.211-218,2000

（2001年 4 月 10 日原稿受理，2001年 9 月 5 日採用決定） 